\title{
Harnessing the Power of Reflective Journal Writing in Global Contexts: A Systematic Literature Review
}

\author{
Anselmus Sudirman* \\ Universitas Sarjanawiyata Tamansiswa, Yogyakarta, Indonesia \\ https://orcid.org/0000-0001-5520-9838 \\ Adria Vitalya Gemilang \\ Universitas Sarjanawiyata Tamansiswa, Yogyakarta, Indonesia \\ https://orcid.org/0000-0002-7784-7811 \\ Thadius Marhendra Adi Kristanto \\ Universitas Sarjanawiyata Tamansiswa, Yogyakarta, Indonesia \\ https://orcid.org/0000-0001-8976-8486
}

\begin{abstract}
This research aimed to describe a critical framework of reflective journal writing that has significant impacts on student writers worldwide and identify the qualities of reflective journal writing that foster transformative practices involving personal, relational, and intellectual activities. This systematic literature review incorporated important theoretical frameworks into acceptable convictions. A thorough analysis of 20 recently published research articles (out of 450) from 2016 to 2021 aimed to present written arguments that support thesis positions and credible evidence, as well as determine the global contexts of writing practices. The findings showed that reflective journal writing reinforced a profound transformation to further explore selfdiscovery, self-inquiry, and critical ideas. It is also concerned with writing performance, as well as the advancement of cognitive and metacognitive writing skills. Reflective journal writers' voices empowered significant changes in a variety of writing aspects, including personal idea exploration, creativity, self-organization, and professional practice development. These findings have implications for encouraging critical reflection, self-expression, and critical thinking among students. They should write reflective journals that can have an impact on a global community and allow them to bring about transformations.
\end{abstract}

Keywords: reflective writing; reflective journal; writing skills; transformative practice; self-inquiry

"Corresponding author: Anselmus Sudirman, anselmus.sudirman@ustjogja.ac.id 


\section{Introduction}

In higher education, reflective journal writing is a means of presenting wellorganized ideas about cognitive and metacognitive knowledge, invaluable learning experiences, and authorial truths. Students can confirm what they have learned and how they have described learning experiences through reflective writing. Recent trends in reflective journal writing have resulted in a slew of studies focusing on two essential elements: (1) integrating theory and practice of formal learning materials (Al-karasneh, 2014), and (2) identifying them through the author's lens of personal experiences, point of view, and professional practice (Boud, 2001). Students investigate such critical aspects of reflective writing to improve critical thinking skills and vocabulary achievement (Laqaei, 2015). This learning model of academic context encourages them to look at things critically.

On the one hand, there is currently a scarcity of specific literature on critical reflection for scholarly journal writing. Journal writing, as a reflexive practice, has the potential to shape emotion, intuition, and empathy (Corbett, 2014). Students improve their ability to solve problems, communicate ideas, and reflectively express emotions. They recognize that an academic writing genre can even foster deep emotions, skills, and academic identity (Cameron et al., 2009). On the other hand, without these characteristics, academic writing, particularly reflective writing, cannot present self-discovery, self-inquiry, and critical reflections. Marsh (2014) referred to this writing practice as "the power and emotional investment" - a motivating factor for student writers to develop a reflective writing tone, human voice, and emotional risks of vulnerability that may shake them in difficult times.

The effectiveness of reflective journal writing has widened the theoretical and practical gap between self-reflection and analysis reflection (Nagao, 2018; Nagao, 2019). The former refers to either a hands-on framework or selfawareness that improves the writing performance of students. This experiential learning is increasingly becoming important for improving writing skills in the intellectual society of the twenty-first century. The latter contributes to critical thinking skills by modelling how reflective journals are assessed more dynamically using given rubrics. The context of reflective journal writing entails acknowledging creative possibilities and actual performance. Thus, the purpose of writing reflective journals is to improve performance-based self-efficacy, flexibility, attitudes, and situational skills. To fill in such a gap, two research questions (RQs) arise in the hope of solving and addressing the problems under discussion and are as follows:

- RQ 1 - What are the powerful aspects of writing reflective journals in global contexts?

- RQ 2 - What attributes does reflective journal writing have in terms of fostering transformative practices? 


\section{The Literature Review}

\subsection{Reflective Journal Writing}

A reflective journal is used in the medical profession to examine self-reflections that include a critical appraisal, peer group discussion, and self-awareness (Riley-Douchet \& Wilson, 1997). It can also be used to capture experiences, record events, explore feelings, and advance in-depth understandings through narrations. Writing a reflective journal, on the other hand, is a form of selfreflective practice in formal or informal learning contexts (Boud, 2001). When dealing with informal topics, students use descriptive writing to take into account previous knowledge, experiences, and observations (Carroll \& Wilson, 2014), but their reflective journals will be less complete if they do not recognize the importance of self-discovery and critical reflection to conceptualize ideas formally.

In a global framework, reflection is a slogan in education that accentuates the consistent use of critical reflections (Liu, 2020), the depth of reflections, and the value of reflective activities (Moon, 2006). Within an academic discipline, students' reflective journals describe both critical thinking and arguments to explore previous common knowledge, learning experiences, and observations (Carroll \& Wilson, 2014). Allan and Driscoll (2014) emphasized that a reflective writing model assesses learning outcomes and fosters learning activities. The faculty gets involved in promoting the professional development of the prospective teachers. However, Lengelle et al. (2013) stressed the importance of reflective writing in the narration of students' real-life experiences to gain insights into the meaning and direction of several expressions that they convey.

Reflective writing is a technique for promoting students' self-development (Rushton \& Duggan, 2013). Reflective journals can ensure the quality of reflective learning and metacognitive thinking (Allan \& Driscoll, 2014). A reflective journal includes self-taught topics like describing imaginations, applying theories, descriptions, and problem-solving issues (Sangvanich \& Chinokul, 2018). In addition, reflective journal writing allows students to improve their self-reflection, personal potential, and problem-solving skills (Rushton \& Duggan, 2013).

Prospective teachers use reflective journals to hone their reflective skills, which include discussion, peer-reviewing, and journal keeping, while internalizing and problematizing the issues at hand (Arikan, 2006). The findings of Arikan's study (2006) showed that prospective teachers are very satisfied with the writing feedback or critical comments made about the content of the reflective journals. In general, prospective teachers can enrol in the writing course to improve their reflective writing skills, practical knowledge, and reflective inquiry. Journal writing has an impact on students' writing styles to elicit information in informative, expressive, and formal tones of topics. Journal writing reflectively identifies students' real-life problems that require feasible solutions in learning English as a foreign language (Hashemi \& Mirzaei, 2015) 


\subsection{Reflective Practice in Reflective Journals}

King et al. (2017) defined reflective practice as a learning process that necessitates personal reflection and reaction to a variety of learning experiences. This didactic concern seeks to articulate critical thinking skills and introspections of ultimately core values of learning and self-awareness of emerging broader issues to investigate. Reflective practice, as the name implies, modifies academic literacies that resonate with perceptions, participation, and reasoning abilities (Abednia et al., 2013). Students use reflective practice to adopt academic rhetoric (Shaw \& Vassileva, 2009), demonstrate reflective practice (Bailes et al., 2010), and foster self-awareness when discussing issues (Abednia et al., 2013). Similarly, reflective practice articulates the socio-cultural or multicultural contexts of learning outcomes, student learning, and engagement (Allan \& Driscoll, 2014; Rushton \& Duggan, 2013; Liu, 2020). Hence, reflective practice is a clear example of academic activity that presents criticism, participation, arguments, and assessment.

More importantly, Bain et al. (1999) contended that journal writing encourages student-teachers to initiate professional reflective practice based on their field experiences while remaining focused on the constructive journal feedback that provides some notes to support the development of reflective skills. The study discovered that giving students feedback on the value of reflections helps them improve their reflective journal writing. Reflective practice has proven to be effective in medical education by enhancing clinical learning, professional growth, and professional development through the creation of reflective journals (Mahlanze \& Sibiya, 2017a). Reflective practice in a pedagogical discipline can improve both theory and practice of teaching. Critical reflective practice is also important for fostering teacher development (Brandenburg \& Jones, 2017), assisting students in deepening their understanding of learning materials, promoting lifelong learning, minimizing clinical errors, and advancing professional autonomy (Harris, \& Jones, 2016). Thus, the reflective practice emphasizes a deeper exploration by checking details, reflecting on the meaning of what is happening, or adding learning experiences to theories.

\section{The Research Methodology}

\subsection{Research Design}

This research is classified as a systematic review of literature because it follows steps in the systematic review process to investigate relevant theoretical frameworks and produce a comprehensive review, which leads to the importance of academic success, as well as the disclosure of ideological and theoretical assumptions (Goagoses \& Koglin, 2020). The systematic literature review focuses on (1) presenting written arguments that support a thesis position by establishing a case using credible evidence from previously published research articles, and (2) determining the context and background of current knowledge of the topics under investigation (Machi \& McEvoy, 2016). The combination of both theoretical frameworks and lines of argument produce what is known as a comprehensive outlook of current research trends, while also sharpening ideologies of writing reflective journals and the extent to which they condone the praxis of transformation in real settings. 


\subsection{Searching and Identifying the Literature}

This research is essentially reliant on literature searches conducted through online academic databases. First, EBSCO offers a variety of research outcomes, including cross-disciplinary e-journals that allow access to high-quality research publications. Second, SAGE Premier is a service that focuses on providing highquality peer-reviewed journals in which papers can be found, with a focus on peer-reviewed publications relevant to the research being investigated. Third, Scopus-Elsevier has a large and growing database where scholars can familiarize themselves with peer-reviewed articles, book chapters, and other related literature. Fourth, Taylor \& Francis Online offers a series of databases from which high-quality peer-reviewed publications can be found in a wide range of fields. Fifth, Springer Link is likely to provide a database of outstanding peerreviewed papers that are still relevant to this research.

To make searching easier, search key terms such as reflective journal, writing, reflective journal writing, and transformative practice of reflective writing were utilized in a wide range of 2016-2021 publications. However, publications published before 2016 were excluded from the query, which was paired with keyword and abstract searches to identify the most relevant published articles.

\subsection{Selection Criteria}

The researcher's main selection criteria included qualitative, quantitative, or mixed-method research for review, as well as primary and secondary literature studies. The article publishing years of 2016-2021 ( $\mathrm{N}=20)$ were strictly selected from the total of 450 articles in the tabulation database, with no regard to the date of publication. For the sake of eligibility, data relevance, and claim qualification (Machi \& McEvoy, 2016), 430 articles were excluded from the initial screening. Similarly, the purpose of incorporating this policy was to examine current research trends or to see how such studies communicate novelties. The following table shows the criteria for inclusion and exclusion.

Table 1: Article review criteria for inclusion and exclusion

\begin{tabular}{|c|c|c|}
\hline Aspects & Inclusion & Exclusion \\
\hline Article category & $\begin{array}{l}\text { 1. Qualitative, quantitative, or } \\
\text { mixed-method research } \\
\text { 2. Systematic literature } \\
\text { reviews } \\
\text { 3. Relevance of the topics } \\
\text { (reflective journal writing, } \\
\text { writing, transformative } \\
\text { practice) } \\
\text { 4. Articles were peer-reviewed } \\
\text { and published in peer- } \\
\text { reviewed journals. } \\
\text { 5. The coverage of publishing } \\
\text { years: 2016-2021 (emphasis } \\
\text { on currency) } \\
\text { 6. Every full-text article was } \\
\text { written entirely in English. } \\
\text { 7. Comprehensiveness and } \\
\text { availability of the articles }\end{array}$ & $\begin{array}{l}\text { 1. Articles of conference } \\
\text { proceedings } \\
\text { 2. Opinions or scientific } \\
\text { articles } \\
\text { 3. Articles that are unrelated } \\
\text { to the topics } \\
\text { 4. Non-currency or out-of- } \\
\text { date articles }\end{array}$ \\
\hline
\end{tabular}




\begin{tabular}{|c|c|c|}
\hline $\begin{array}{l}\text { Types of writing } \\
\text { conditions or } \\
\text { backgrounds }\end{array}$ & $\begin{array}{l}\text { 1. Reflective journals, writing, } \\
\text { reflective journal writing, } \\
\text { and transformative practice } \\
\text { articles are conditioned to } \\
\text { highlight various writing } \\
\text { genre backgrounds. } \\
\text { 2. They can back up the } \\
\text { authors' arguments and } \\
\text { assertions in expressing their } \\
\text { research findings and results, } \\
\text { which are all based on } \\
\text { authorship, breadth, topical } \\
\text { relevance, and currency } \\
\text { criteria. }\end{array}$ & $\begin{array}{l}\text { 1. Because of their lack of } \\
\text { topicality, breadth, } \\
\text { relevance, and authorship } \\
\text { considerations( Efron \& } \\
\text { Ravid, 2019), articles on } \\
\text { academic writing contexts, } \\
\text { opinions articles, and } \\
\text { scientific reviews are } \\
\text { excluded from the database. } \\
\text { 2. They are the outcome of } \\
\text { untrustworthy sources, } \\
\text { such as articles that are } \\
\text { published without going } \\
\text { through peer review } \\
\text { procedures. }\end{array}$ \\
\hline Themes of research & $\begin{array}{l}\text { 1. Reflective writing } \\
\text { 2. Writing } \\
\text { 3. The praxis of transformation } \\
\text { in writing, and } \\
\text { 4. Reflective journal writing }\end{array}$ & $\begin{array}{l}\text { Articles that do not match the } \\
\text { themes include: } \\
\text { 1. Reflective writing, } \\
\text { 2. Writing, } \\
\text { 3. Transformational writing } \\
\text { praxis, and } \\
\text { 4. Reflective journal writing }\end{array}$ \\
\hline
\end{tabular}

\subsection{Risk of Bias and Quality Assessment}

This systematic literature review employed a research methodology (Snyder, 2019) to identify articles that have been thoroughly investigated. Researchers can be vulnerable to bias by ignoring the critical attitude that the conduct of the review must follow quality standards, especially in observing aspects of scientific writing, trust in the results and findings from an in-depth exploration of the articles, due to the wide variety of research approaches used to assess aspects of writing from a transformative point of view. In a nutshell, the focus of the systematic literature review is on the reliability and quality of the review articles (Snyder, 2019).

Systematic literature reviews, like other studies, run the risk of bias in source selection due to factors closely related to the formal protocols developed and made public before conducting the review. Reporting bias may occur if the researcher deviates from the protocol in terms of data selection. Furthermore, when a systematic review fails to identify all available data on a topic, evidence selection bias occurs (Drucker et al., 2016). As a result, the researcher carefully examines ideas and establishes the relationship between content and concepts, a process known as context-sensitive (Harris, 2020), which refers to the purpose of writing based on context and sensitivity to the issues raised by the authors of the articles.

The quality assurance assessment is carried out by providing checklists that outline the points at which the correlations of the review section are linked, such as how the researcher determines the type of review, database search, and categorization (Goagoses \& Koglin, 2020), specifically in the field of reflective journal writing, writing, and transformative practices across disciplines. 


\subsection{Data Extraction}

It is critical to extract data from the studies that have been included (Jonnalagadda et al., 2015). In a systematic literature review, researchers created and evaluated standard extraction in line with the applicable provisions. A conceptual framework related to the discussion areas of reflective journaling, writing, reflective journal writing, transformative practice of writing in global contexts, year of publication, type of research, and the author are among the essential information that will be extracted from the database.

In addition, sorting aspects of the suitable research approach, geographical location of the country, and research costs, if necessary, are crucial extraction components. Researchers also look at whether literature research has to be packaged as a scientific work that has gone through rigorous peer-review processes and takes a long time to complete, as evidenced by the article history. Ultimately, they must map the research gaps to maintain the accuracy of the documents provided while also identifying relevant articles and theoretical information to extract (Goagoses \& Koglin, 2020).

\subsection{Data Analysis}

The researchers analyzed the data in several ways, including (1) studying the research findings to elicit information on the relevance of the methodologies and the results, (2) evaluating ways in which articles on reflective journal writing can be identified as having assessment scales, (3) measuring conceptualizations as seen in the tabulated database, (4) coding the data within the research coverage to compile the range of measurement (Tai et al., 2020; Machi \& McEvoy, 2016), and (5) evaluating ways in which articles on reflective journal writing can be identified as having assessment criteria scales.

\section{Results and Discussion}

\subsection{The Powerful Aspects of Writing Reflective Journals in Global Contexts}

According to the research findings, a powerful aspect that contributes to positive vibes is required when writing a reflective journal. Reflective journals have proven to be a useful tool for encouraging critical thinking in the health sector. Furthermore, self-criticism about the likelihood of expressing ideas and the extent to which key principles are represented clearly in written work is a major emphasis of reflections. Students can write confidently in reflective journals because they are not subject to censorship. They can prioritize humanity, local culture, comprehensive patient care, self-evaluation, self-study, self-knowledge, and problem-solving abilities (Murillo-Llorente et al., 2021).

In other cases, reflective journal writers focus on personal and professional development, to maximize self-aptitude and potential in future professions. Problem-solving abilities, proactive decision-making, and corrective action, as well as extending self-awareness and strengthening writing skills, are all challenges for therapeutic learning in reflective journal writing (Murillo-Llorente et al., 2021). As a result, reflective journal writers must maintain self-reflection, self-emancipation, and full engagement to improve comprehension, self-efficacy, critical thinking abilities, critical reflection, and positive assessment (Hwang et al., 2018). Reflective thoughts, transformative experiences, and learning 
reflections are becoming increasingly common among nursing students' reflective journals. They can do cognitive tasks and evaluate writing performance using an evaluation tool with a scoring rubric if they maintain consistency in their writing. To preserve academic achievement, they keep the track record of autonomous learning, self-awareness, personal growth, and selfreflection (Or, 2018).

In the social sciences, reflective journal writing shapes students' perspectives on enriching personal experiences, enhancing comprehension of transferrable skills, core values, and self-awareness. Reflective journaling, according to other experts, necessitates full engagement, self-expression, and critical reflection when expressing ideas. Nursing students can engage in transformative practices, build investigation skills, and provide detailed descriptions (Szenes \&Tilakaratna, 2021). In essence, self-reflection and ongoing metacognitive growth are re-articulated in reflective journals. When writing reflectively, they call into question their self-control, self-awareness, and self-evaluation (Ramadhanti et al., 2020).

In the field of language/EFL, reflective journal writers emphasize the nature of reflective writing as a medium for developing writing abilities and cultivating desired educational knowledge. Cognitive development demands behaviour management, and critical reflection that can strengthen reflective practice and increase self-awareness (Arthur \& Arthur, 2021). In this sense, writing a reflective journal can help students become more active in cooperative learning and problem-solving. Forming a habit of negotiation and critical thinking is another way to improve students' rational thinking skills. This justification is based on their ability to think in a way that allows them to continue learning throughout their lives (Ahmed, 2019). The problem of how students acquire critical reflection is another important aspect of this review. Critical thinking is never separated from metacognitive skills, and it is completely supported in the development of writing skills through self-editing and self-inquiry (Sudirman et al., 2021).

Because this activity emphasizes accuracy, diversity, and growth in reflective thinking, the features of reflective writing facilitation, namely reflectivity, thoroughness, variety, and growth, are a primary concern in educational sciences. Classroom management, lecturer flexibility, and time management are all factors that encourage students to be improved cognitively and metacognitively by demonstrating class performance and reflective thinking (Barham et al., 2019). They can use reflective practice and metacognitive strategies to bridge the gap between theory and practice, while also promoting critical reflection, feedback efficacy, self-awareness, and evidence-based learning (Bruno \& Dell'Aversana,2017). That way, they promote academic literacy, reflective thinking, transformative practice, and transitional writing as contested and negotiated discourses (Vassilaki, 2017).

Since students reflectively engage in dialogue, reflective journal writing intends to generate effective and lifelong changes, making learning more relevant, 
contextual, and meaningful. They focus on personal development, observation skills, reflective learning, and uncensored writing (Ahmed, 2020) through critical and reflective thinking, so that the use of social skills and personal voice continues to receive mutual support in the struggle for teamwork, reflection, criticism, self-analysis, and metacognitive skills (Bashan \& Holsblat, 2017). All of these activities can help individuals achieve long-term goals by promoting personal and professional development, personal reflection, critical thinking, independent learning, and intrinsic motivation(Yu \& Chiu, 2019).

Through reflective journal writing, students can acquire critical awareness and new views in the music, applied sciences, and learning domains, allowing them to solve problems, engage in self-directed learning, express feelings, and stimulate personal growth (Woronchak \& Comeau, 2016). They follow a cycle of self-evaluation, learning-related actions, positive ideals, and values through independent learning (Hensley \& Munn, 2020). In short, reflective journals can certainly assist them with critical thinking and conceptual learning. This trigger also can shape knowledge transformation, such as conceptual problem solving that leads to metacognitive and rhetorical transformation, the actual writing, direct instruction, corrective sequences, and reflective practice (Herder et al., 2018). The table below reflects the complete description.

Table 2: Powerful aspects of writing reflective journals worldwide

\begin{tabular}{|c|c|c|c|c|}
\hline No & $\begin{array}{l}\text { Type of } \\
\text { Research }\end{array}$ & $\begin{array}{l}\text { Powerful Aspects of Writing } \\
\text { Reflective Journals }\end{array}$ & Country & Field \\
\hline 1 & Qualitative & $\begin{array}{l}\text { Nurturing critical thinking, self- } \\
\text { criticism, core values, skills, self- } \\
\text { confidence, humanity, local culture, } \\
\text { comprehensive care, self-evaluation, } \\
\text { self-learning, self-knowledge, and } \\
\text { problem-solving skills (Murillo- } \\
\text { Llorente et al., 2021) }\end{array}$ & Spain & $\begin{array}{l}\text { Health } \\
\text { sciences }\end{array}$ \\
\hline 2 & Qualitative & $\begin{array}{l}\text { Enriching personal experiences, } \\
\text { transferrable skills, core values, self- } \\
\text { awareness, engagement, self- } \\
\text { expression, critical reflections, } \\
\text { transformative practice, exploratory } \\
\text { and explanatory skills (Szenes \& } \\
\text { Tilakaratna, 2021) }\end{array}$ & Australia & $\begin{array}{l}\text { Social } \\
\text { sciences }\end{array}$ \\
\hline 3 & Qualitative & $\begin{array}{l}\text { Re-articulating self-reflection, } \\
\text { metacognitive growth, self- } \\
\text { questioning, self-regulation, self- } \\
\text { control, self-awareness, and self- } \\
\text { evaluation (Ramadhanti et al., 2020) }\end{array}$ & Indonesia & $\begin{array}{c}\text { Social } \\
\text { sciences }\end{array}$ \\
\hline 4 & Qualitative & $\begin{array}{l}\text { Emphasizing desirable pedagogical } \\
\text { skills and knowledge, cognitive } \\
\text { growth, behavioural management, } \\
\text { critical reflections, reflective practice, } \\
\text { and self-improvements (Arthur \& } \\
\text { Arthur, 2021) }\end{array}$ & Ghana & Language \\
\hline 5 & Quantitative & $\begin{array}{l}\text { Regarding personal and professional } \\
\text { development, a tool for clinical }\end{array}$ & $\begin{array}{l}\text { South } \\
\text { Africa }\end{array}$ & Nursing \\
\hline
\end{tabular}




\begin{tabular}{|c|c|c|c|c|}
\hline & & $\begin{array}{l}\text { learning, problem-solving skills, } \\
\text { proactive decision-making, corrective } \\
\text { actions, self-awareness, and writing } \\
\text { skills (Mahlanze \& Sibiya, 2017b) }\end{array}$ & & \\
\hline 6 & Qualitative & $\begin{array}{l}\text { Maintaining self-reflection, self- } \\
\text { emancipation, full engagement, } \\
\text { increased understanding, self- } \\
\text { efficacy, critical thinking skills, } \\
\text { critical reflections, critical reflective } \\
\text { journaling, and positive evaluations } \\
\text { (Hwang et al.,2018) }\end{array}$ & $\begin{array}{l}\text { South } \\
\text { Africa }\end{array}$ & Nursing \\
\hline 7 & Quantitative & $\begin{array}{l}\text { Facilitating dimensions reflective } \\
\text { writing, classroom management, } \\
\text { teacher flexibility, time management, } \\
\text { classroom performance, and } \\
\text { reflective thinking (Barham et al., } \\
\text { 2019) }\end{array}$ & Qatar & Education \\
\hline 8 & $\begin{array}{l}\text { Mixed } \\
\text { methods }\end{array}$ & $\begin{array}{l}\text { Implementing reflective practice, } \\
\text { metacognitive strategy, theory and } \\
\text { practice linkages, critical reflection, } \\
\text { feedback efficacy, self-awareness, } \\
\text { and evidenced-based learning (Bruno } \\
\text { \& Dell' Aversana, 2017) }\end{array}$ & Italy & $\begin{array}{l}\text { Educational } \\
\text { sciences }\end{array}$ \\
\hline 9 & $\begin{array}{l}\text { Interpretive } \\
\text { qualitative }\end{array}$ & $\begin{array}{l}\text { Enhancing cooperative learning, } \\
\text { students' } \\
\text { negotiations and croblem-solving, } \\
\text { thinking skills, and lifelong learning } \\
\text { (Ahmed, 2019) }\end{array}$ & Egypt & EFL \\
\hline 10 & $\begin{array}{l}\text { Explorative } \\
\text { qualitative }\end{array}$ & $\begin{array}{l}\begin{array}{l}\text { Stimulating critical } \\
\text { conceptual learning, } \\
\text { transformation, } \\
\text { knowledgens, } \\
\text { conceptual, }\end{array} \\
\text { metacognitive, and rhetorical } \\
\text { problems, the actual writing, hands- } \\
\text { on instructions, correction sequences, } \\
\text { and reflective practices (Herder et al., } \\
2018 \text { ) }\end{array}$ & Netherlands & $\begin{array}{l}\text { Applied } \\
\text { sciences }\end{array}$ \\
\hline 11 & Qualitative & $\begin{array}{l}\text { Developing critical reflection, critical } \\
\text { thinking, metacognitive skills, self- } \\
\text { editing, self-inquiry, and writing } \\
\text { skills (Sudirman et al., 2021) }\end{array}$ & Indonesia & Language \\
\hline 12 & Qualitative & $\begin{array}{l}\text { Practicing academic literacy, } \\
\text { reflective thinking, transformative } \\
\text { practice, transitional writing, } \\
\text { contested and negotiated discourse } \\
\text { (Vassilaki, 2017) }\end{array}$ & Greece & Education \\
\hline 13 & $\begin{array}{l}\text { Literature } \\
\text { Review }\end{array}$ & $\begin{array}{l}\text { Understanding abstract concepts, } \\
\text { individual and collective } \\
\text { development, self-evaluation, critical } \\
\text { thinking, reflective practice, and } \\
\text { analytical skills (Power, 2017) }\end{array}$ & Thailand & $\begin{array}{l}\text { Humanities } \\
\text { and } \\
\text { language }\end{array}$ \\
\hline 14 & $\begin{array}{l}\text { Quasi- } \\
\text { experimental }\end{array}$ & $\begin{array}{l}\text { Reflective thinking, transformative } \\
\text { experiences, learning reflection, } \\
\text { cognitive activity, assessment tool, }\end{array}$ & Hong Kong & Health \\
\hline
\end{tabular}




\begin{tabular}{|c|c|c|c|c|}
\hline & & $\begin{array}{l}\text { self-reflection, academic } \\
\text { performance, self-regulated learning, } \\
\text { self-awareness and personal growth } \\
(\text { Or, 2018) }\end{array}$ & & \\
\hline 15 & Qualitative & $\begin{array}{l}\text { Promoting effective and lifelong } \\
\text { changes, reflectively engaged in } \\
\text { dialogue, making more relevant, } \\
\text { contextual, and meaningful learning, } \\
\text { critical thinking, personal } \\
\text { development, improving observation } \\
\text { skills, critical reflections, reflective } \\
\text { learning, and uncensored writing } \\
\text { (Ahmed, 2020) }\end{array}$ & Qatar & Education \\
\hline 16 & Qualitative & $\begin{array}{l}\text { Harnessing social skills, personal } \\
\text { voices, teamwork, reflection, } \\
\text { criticism, self-analysis, and } \\
\text { metacognitive skills (Bashan \& } \\
\text { Holsblat, 2017) }\end{array}$ & Israel & Education \\
\hline 17 & Qualitative & $\begin{array}{l}\text { Promoting professional } \\
\text { development, local EFL contexts, } \\
\text { narrative practice, improvement of } \\
\text { communication abilities, critical } \\
\text { thinking skills, and language skills } \\
\text { (Yoshihara et al., 2020) }\end{array}$ & Japan & $\overline{E F L}$ \\
\hline 18 & Qualitative & $\begin{array}{l}\text { Developing critical awareness and } \\
\text { new perspectives, problem-solving } \\
\text { abilities, and self-learning abilities, } \\
\text { expressing feelings, and promoting } \\
\text { personal growth (Woronchak \& } \\
\text { Comeau, 2016). }\end{array}$ & Canada & Music \\
\hline 19 & Qualitative & $\begin{array}{l}\text { Fostering self-regulated learning, a } \\
\text { cyclical process of self-evaluation, } \\
\text { learning-related actions, positive } \\
\text { thoughts, and feelings (Hensley \& } \\
\text { Munn, 2020) }\end{array}$ & USA & Learning \\
\hline 20 & $\begin{array}{l}\text { Mixed } \\
\text { methods }\end{array}$ & $\begin{array}{l}\text { Enhancing personal and professional } \\
\text { growth, personal reflections, critical } \\
\text { thinking, self-learning, and intrinsic } \\
\text { motivation } \\
\text { (Yu \& Chiu, 2019) }\end{array}$ & Hong Kong & Education \\
\hline
\end{tabular}

\subsection{Reflective Journal Writing and its Determining Factors}

Writing is an essential component of performance. Several factors contribute to the advancement of this academic act, particularly those related to the effect, virtuality, abstraction, and embodiment of performance (Harris \& Jones, 2016). One of the primary goals of writing is to encourage student writers to continue developing their writing skills, and a more comprehensive approach to teaching writing necessitates teachers attempting to show a growing interest in optimizing students' cognitive performance (Zarrabi \& Bozorgian, 2020). Teachers can track their students' writing performance throughout this approach and set examples of other performance makers (Harris, \& Jones, 2016) to 
motivate others to make progress. A high frequency of revisions, consultations, and active writing is required for the best writing performance (Zarrabi \& Bozorgian, 2020). This pedagogical model promotes students' understanding of writing theories and their application in learning settings. They are capable of meeting the required writing standards. The lecturers' critical comments, on the other hand, should embody writing principles in order to help students gain insights into revisions, reorganize ideas, and resubmit them.

The effectiveness of an e-portfolio in improving writing performance is greater than that of a traditional portfolio because it can retain accessibility, flexibility, and interactive features when students are subjected to social pressures that cause them to be more reflective and sensitive to writing stages (Barrot, 2020). It implies that reflectivity and sensitivity can both provide a wide range of writing practices. Students demonstrate writing performances that foster inherent interconnections of ideas and self-discovery within this scope of learning. The paradigm of self-inquiry can be derived from analytical and critical perspectives (Herrero-Martín, 2021) that shed light on endless opportunities to write on the internet (Şentürk, 2021). Students should become acquainted with technologyenhanced instructions in an English writing course (Zou \& Xie, 2019) by using devices such as: Myspace, Facebook, Twitter, Instagram, Google docs, multiple blogs, and national media sites (Şentürk, 2021). Another researcher claimed that Moodle English journal writing influences students' writing performance, performance assessment to improve students' writing skills (Suastra \& Menggo, 2020), and conjunction preferences and self-efficacy (Yang, 2020). In summary, technology-enhanced writing has been a viable option for students seeking to develop writing skills that positively correlate with the use of technological devices.

Meanwhile, metacognitive knowledge (conditional knowledge, procedural knowledge, declarative knowledge, monitoring, planning, and evaluating) and other related regulations are important factors in improving the writing performance of students (Teng, 2020b). Writing performance is associated with performative pedagogies of creative writing practice (Williams, 2019), which emphasize the transformation of the creative writing program through collaborative writing. To consider the reflective practice in developing ideas that leads to a framework of thoughts, students must explore a series of reflections in the program (Cendon, 2020). The goal of writing performance is to improve students' metacognitive strategy regarding either knowledge of writing proficiency or self-evaluation in multimedia situations (Qin \& Zhang, 2019). Aside from the obvious concern, students should demonstrate their writing quality, which includes dimensions of a strong authorial voice and textual quality (Zabihi et al., 2019). Writing performance, as a whole, focuses on the development of metacognitive skills, performance-based pedagogies, and reflective practices to maintain desirable writing quality.

Within a context of active learning and thinking, writing performance requires both cognitive and metacognitive levels of abilities (Michel et al., 2019; Lee \& Mak, 2018; Teng, 2020a) using the assessment indicators of Online Peer Feedback $(\mathrm{OPF})$, Automated Corrective Feedback (ACF), Indirect Codded Correction 
Feedback (ICCF), and short affective comments involving grammatical accuracy, sentence complexity, lexical density, motivation, and guidance (Shang, 2019; Mujtaba et al., 2020). This writing performance presents performativity through the assessment of academic writers' assignments (Reinertsen \& Thomas, 2019), each of which contains evident errors or flaws concerning arguments (Hennessy, 1997). Reflective journal writing can improve course performance if students get engaged in reflective thinking (Cisero, 2006) through reflective writing and mentoring activities (Stevens et al., 2010), as summed up in the following diagram.

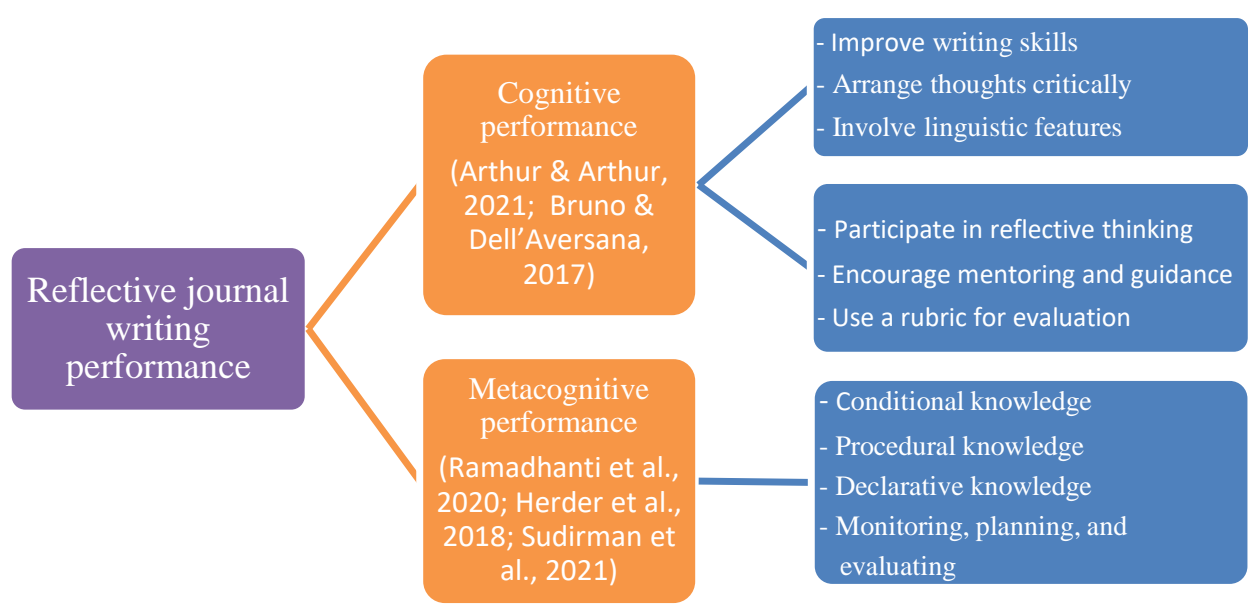

\section{Diagram 1. Performance in reflective journal writing}

\subsection{The Attributes of Reflective Journal Writing that Foster Transformative Practices}

The practice of reflective journal writing in the digital age aims to improve students' critical thinking and reflection skills. The textual messages underlying the efficacy of writing have been used to generate ideas reflectively. This is understandable given that the goal of reflective writing is to promote educational concepts that transcend time and space and are aligned with transformative practices (Phillips \& Archer-Lean, 2019; Coleman \& Tuck, 2020). Etymologically, the term transformative refers to a significant change in a person's attitude or character. A transformative practice is another term for a planned activity in which changes in performance, work systems, and living arrangements are directly related to mental attitudes, conditions, and social structures.

Transformative practice in reflective writing is mainly concerned with personal, relational, institutional, and global issues that bring about pedagogical changes (Coleman \& Tuck, 2020). Such fundamental aspects continue to encourage students to express human values, honesty, and justice. At this level, writing can stimulate self-inquiry, self-discovery (Matousek, 2017), critical explorations of ideas (Fisher, 2011), and the likelihood of taking on a series of assignments.

Writing, as a result of personal and intellectual activities, has become an important component of the digital revolution, giving rise to digital writing outputs (Brennan, 2018). Therefore, a student writer provides a space for digital 
writing activities (Christiansen, 2017; De Pew \& Miller, 2005). It aims to mold the personality, mindset, behaviour, and lifestyle of digital readers. In this sense, digital writing necessitates a mental revolution because its goal is to transform online readers and the digital society. The author's voice will have transformative power (Black, 2019; Matousek, 2017), echoing significant changes embodied in various aspects of life, particularly creative writing on political, economic, educational, tolerance, multi, and socio-cultural topics. In the digital age, the author's voice is the voice of character education (Jerome \& Kisby, 2020; Jerome \& Kisby, 2019). Reflective journal writing leads to transformative practice within communities or groups of writers, as shown in the diagram below.

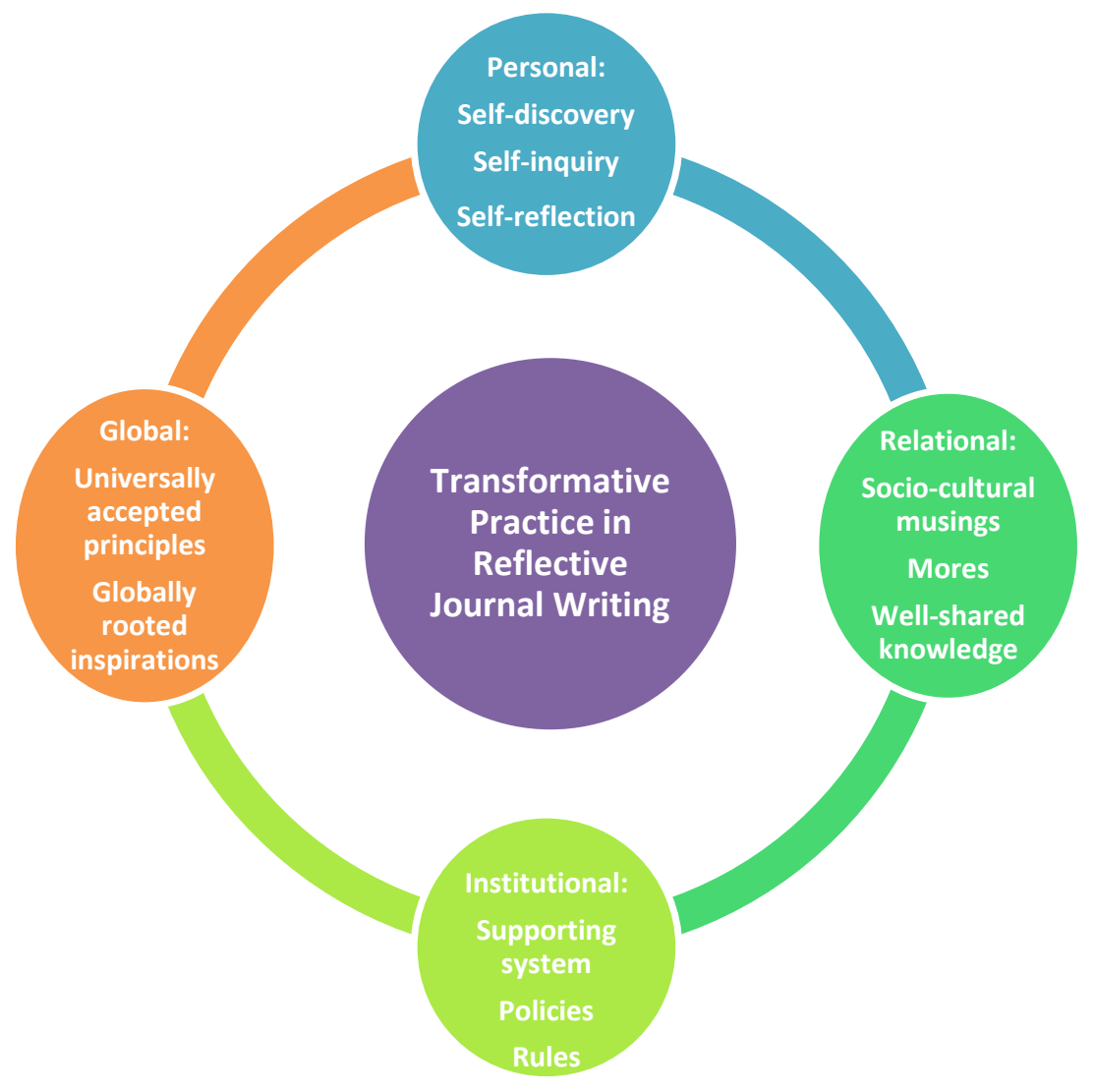

Diagram 2. Transformative practice in reflective journal writing

\section{Conclusion and Recommendations}

Reflective journal writing is a thinking process in which students describe a series of real and imaginary activities. Its strength lies in the depth of critical arguments, inquiry-based interactions, and self-reflective thoughts in learning contexts involving personal emotions and social circumstances. This idea dispels the notion that reflective journal writing is not only descriptive but also explorative. Students must check scientific details of data, reflect on academic activities from previous learning sessions, and relate them to existing theories and points of view.

Reflective journal writing, on the other hand, entails descriptions and explorations of various academic activities, cognitive and metacognitive skills. 
Writing academic works that involve subjects, thought processes, and lines of argument are not always easy. Writing about worries, feelings, and mistakes, on the other hand, may lead to the pitfall of interacting without clarity of reasoning because students are subjective in how they express their ideas. This tendency leads to additional insights, self-inquiries, and self-discoveries, and reflective journal writers are unable to avoid the temptation of subjectivity in describing events.

The power of reflective journal writing encourages students to achieve a writing performance that is divided into two major categories. First, cognitive performance is intended to assist them in developing writing skills, organizing critical ideas, engaging in reflective thinking, mentoring, assessment, and guidance. Second, metacognitive abilities produce conditional, procedural, and declarative knowledge, as well as monitoring, planning, and evaluating performance. Further researchers are recommended to use an application to analyze articles concerning reflective journal writing as an intellectual activity aiming at voicing transformations of a global community. One of the reflective writer's responsibilities is to address educational ideas that can cross time and space boundaries so that readers are fully aware of transformation in all circles.

\section{Practical Implications}

In global contexts, reflective journal writing is a process of expressing critical and reflective ideas. Students make an effort to write independently even when they are experiencing anxiety, worry, grief, and stress. In this sense, a reflective writing journal, also known as expressive writing, is a panacea for painful emotions that improves health by narrating distressing life experiences (Park et al., 2016). Emotive writing is another term for a writing cure that promotes the recovery of stress and working memory. Emotive writing is another term for writing therapy that promotes stress and working memory recovery (Klein, 2002). Writing a reflective journal expresses psychological conditions within the context of social difficulties in life. It has a wide range of effects on stressful experiences and their psychological effects on health. Globally, the goal of expressive writing is to promote the recovery of fragile emotions.

\section{Research Limitations}

This research has two limitations: (1) the number of reflective journals is small, and they do not completely strengthen transformative actions. Even students rearticulate personal, relational, institutional, and global writing powers without using technological platforms; and (2) using articles from various disciplines cannot determine the transformative effects of reflective journal writing because it does not result in a significant change in a person's attitude or character. Transformative means the total awareness achieved through changes in performance, work systems, and living arrangements that are directly related to mental attitudes, conditions, and social structures. Students use reflective journals to gain access to challenges and opportunities in big data, mobility, and extensive information coverage. 


\section{Acknowledgment}

The authors would like to express their gratitude to the Institute for Research and Community Service (LP3M), Universitas Sarjanawiyata Tamansiswa, Yogyakarta, Indonesia, for providing the research funding (Research Grant No.37/UST/LP3M/PUSLIT/PDU/K/VII/2020).

\section{References}

Abednia, A., Hovassapian, A., Teimournezhad, S., \& Ghanbari, N. (2013). Reflective journal writing: Exploring in-service EFL teachers' perceptions. System, 41(3), 503-514. https://doi.org/10.1016/j.system.2013.05.003

Ahmed, A. M. (2019). Students' reflective journaling: An impactful strategy that informs instructional practices in an EFL writing university context in Qatar. Reflective Practice, 20(4), 483-500. https:// doi.org/10.1080/14623943.2019.1638246

Ahmed, A. M. (2020). From reluctance to addiction: The impact of reflective journals on Qatari undergraduate students' learning. Reflective Practice, 21(2), 251-270. https:// doi.org/10.1080/14623943.2020.1735328

Al-karasneh, S. M. (2014). Reflective journal writing as a tool to teach aspects of social studies. European Journal of Education, 49(3), 395-408. https://doi.org/10.1111/ejed.12084

Allan, E. G., \& Driscoll, D. L. (2014). The three-fold benefit of reflective writing: Improving program assessment, student learning, and faculty professional development. Assessing Writing, 21, 37-55. https:// doi.org/10.1016/j.asw.2014.03.001

Arikan, A. (2006). The value of reflection in writing courses in ELT preservice teacher education programs. Online Submission, 16, 1-16.

Arthur, C., \& Arthur, T. S. (2021). Reflective journal writing: Attitudes of pre-service teachers. International Journal of Technology \& Management Research, 6(2), 129-138. https://doi.org/https://doi.org/10.47127/ijtmr.v6i2.133

Bailes, C. N., Hulsebosch, P., \& Martin, D. S. (2010). Reflective journal writing: Deaf preservice teachers with hearing children. Teacher Education and Special Education: The Journal of the Teacher Education Division of the Council for Exceptional Children, 33(3), 234-247. https://doi.org/10.1177/0888406409356763

Bain, J. D., Ballantyne, R., Packer, J., \& Mills, C. (1999). Using journal writing to enhance student teachers' reflectivity during field experience placements. Teachers and Teaching, 5(1), 51-73. https://doi.org/10.1080/1354060990050104

Barham, A. I., Mohammad, E. G., \& Miqdadi, R. (2019). Reflective journal writing and classroom performance: Improvement and correlation among pre-service mathematics and science teachers. International Journal of Learning, Teaching and Educational Research, 18(11), 348-369. https:// doi.org/10.26803/ijlter.18.11.21

Barrot, J. S. (2020). Effects of Facebook-based e-portfolio on ESL learners' writing performance. Language, Culture and Curriculum, 1-17. https:// doi.org/10.1080/07908318.2020.1745822

Bashan, B., \& Holsblat, R. (2017). Reflective journals as a research tool: The case of student teachers' development of teamwork. Cogent Education, 4(1). https://doi.org/10.1080/2331186X.2017.1374234

Black, A. L. (2019). Digesting a life: Embodying transformation through creative writing. New Writing, 16(1), 50-58. https:// doi.org/10.1080/14790726.2018.1490774

Boud, D. (2001). Using journal writing to enhance reflective practice. New Directions for Adult and Continuing Education, 2001(90), 9. https://doi.org/10.1002/ace.16

Brandenburg, R., \& Jones, M. (2017). Toward transformative reflective practice in teacher 
education . https://doi.org/10.1007/978-981-10-3431-2_14

Brennan, C. (2018). Digital humanities, digital methods, digital history, and digital outputs: History writing and the digital revolution. History Compass, 16(10), e12492. https://doi.org/10.1111/hic3.12492

Bruno, A., \& Dell'Aversana, G. (2017). Reflective practice for psychology students: The use of reflective journal feedback in higher education. Psychology Learning $\mathcal{E}$ Teaching, 16(2), 248-260. https:/ / doi.org/10.1177/1475725716686288

Cameron, J., Nairn, K., \& Higgins, J. (2009). Demystifying academic writing: Reflections on emotions, know-how and academic identity. Journal of Geography in Higher Education, 33(2), 269-284. https:// doi.org/10.1080/03098260902734943

Carroll, J. A., \& Wilson, E. E. (2014). The critical writer: Inquiry and the writing process. California: ABC-CLIO, LLC.

Cendon, E. (2020). From reflective practice to critical thinking https:// doi.org/10.4018/978-1-7998-1238-8.ch008

Christiansen, M. S. (2017). Language use in social network sites: The influence of orality in the digital writing of Mexican bilinguals. Writing \& Pedagogy, 9(2), 369-392. https://doi.org/10.1558/wap.30281

Cisero, C. A. (2006). Does reflective journal writing improve course performance? College Teaching, 54(2), 231-236. https:// doi.org/10.3200/CTCH.54.2.231-236

Coleman, L., \& Tuck, J. (2020). Understanding student writing from lecturers' perspectives: Acknowledging pedagogic complexity to support transformative practices in context. Studies in Higher Education, 1-13. https:// doi.org/10.1080/03075079.2019.1711043

Corbett, J. (2014). Practising reflection: Empathy, emotion and intuition in political life writing. Life Writing, 11(3), 349-365. https:// doi.org/10.1080/14484528.2013.822390

De Pew, K. E., \& Miller, S. K. (2005). Studying L2 writers' digital writing: An argument for post-critical methods. Computers and Composition, 22(3), 259-278. https:// doi.org/10.1016/j.compcom.2005.05.001

Drucker, A. M., Fleming, P., \& Chan, A.-W. (2016). Research techniques made simple: Assessing risk of bias in systematic reviews. Journal of Investigative Dermatology, 136(11), e109-e114. https:// doi.org/10.1016/j.jid.2016.08.021

Efron, S. E., \& Ravid, R. (2019). Writing the literature review: A practical guide. New York: The Guilford Press.

Fisher, M. H. (2011). Postcolonial travel writing: Critical explorations (review). Biography, 34(2), 355-357. https://doi.org/10.1353/ bio.2011.0030

Goagoses, N., \& Koglin, U. (2020). The role of social goals in academic success: Recounting the process of conducting a systematic review. In O. ZawackiRichter, M. Kerres, S. Bedenlier, M. Bond \& K. Buntins (Ed.), Systematic reviews in educational research methodology, perspectives and application (pp. 145-161). Wiesbaden: Springer Fachmedien Wiesbaden. https://doi.org/10.1007/978-3658-27602-7_9

Harris, A. , \& Jones, S. H. (2016). Writing for performance. Boston: SensePublishers.

Harris, D. (2020). Literature review and research design: A guide to effective research practice. New York: Routledge.

Hashemi, Z., \& Mirzaei, T. (2015). Conversations of the mind: The impact of journal writing on enhancing EFL medical students' reflections, attitudes, and sense of self. Procedia - Social and Behavioral Sciences, 199, 103-110. https:// doi.org/10.1016/j.sbspro.2015.07.493

Hennessy, B. (1997). Writing an essay: How to improve your performance for coursework and 
examinations. Oxford: How To Books Ltd.

Hensley, L. C., \& Munn, K. J. (2020). The power of writing about procrastination: Journaling as a tool for change. Journal of Further and Higher Education, 44(10), 1450-1465. https://doi.org/10.1080/0309877X.2019.1702154

Herder, A., Berenst, J., de Glopper, K., \& Koole, T. (2018). Reflective practices in collaborative writing of primary school students. International Journal of Educational Research, 90, 160-174. https://doi.org/10.1016/j.ijer.2018.06.004

Herrero-Martín, R. (2021). The immanent presence of the home language in the foreign language classroom under the transformative-holistic pedagogical paradigm. https:// doi.org/10.4018/978-1-7998-4075-6.ch002

Hwang, B., Choi, H., Kim, S., Kim, S., Ko, H., \& Kim, J. (2018). Facilitating student learning with critical reflective journaling in psychiatric mental health nursing clinical education: A qualitative study. Nurse Education Today, 69, 159-164. https://doi.org/10.1016/j.nedt.2018.07.015

Jerome, L., \& Kisby, B. (2019). The rise of character education in Britain. Cham: Springer International Publishing. https://doi.org/10.1007/978-3-030-27761-1

Jerome, L., \& Kisby, B. (2020). Lessons in character education: Incorporating neoliberal learning in classroom resources. Critical Studies in Education, 1-16. https://doi.org/10.1080/17508487.2020.1733037

Jonnalagadda, S. R., Goyal, P., \& Huffman, M. D. (2015). Automating data extraction in systematic reviews: A systematic review. Systematic Reviews, 4(1), 78. https:// doi.org/10.1186/s13643-015-0066-7

King, A. E., Joseph, A. S., \& Umland, E. M. (2017). Student perceptions of the impact and value of incorporation of reflective writing across a pharmacy curriculum. Currents in Pharmacy Teaching and Learning, 9(5), 770-778. https://doi.org/10.1016/j.cpt1.2017.05.010

Klein, K. (2002). Stress, expressive writing, and working memory. In S. J. Lepore \& J. M. Smyth (Eds.), The writing cure: How expressive writing promotes health and emotional well-being. (pp. 135-155). Washington: American Psychological Association. https://doi.org/10.1037/10451-007

Laqaei, N. (2015). The impact of reflective writing on writing achievement, vocabulary achievement and critical thinking of intermediate EFL learners. Journal of Studies in Education, 5(3), 174. https:// doi.org/10.5296/jse.v5i3.7964

Lee, I., \& Mak, P. (2018). Metacognition and metacognitive instruction in second language writing classrooms. TESOL Quarterly, 52(4), 1085-1097. https:// doi.org/10.1002/tesq.436

Lengelle, R., Meijers, F., Poell, R., \& Post, M. (2013). The effects of creative, expressive, and reflective writing on career learning: An explorative study. Journal of Vocational Behavior, 83(3), 419-427. https://doi.org/10.1016/j.jvb.2013.06.014

Liu, K. (2020). Critical reflection for transformative learning. Cham: Springer International Publishing. https://doi.org/10.1007/978-3-319-01955-0

Machi, L. A., \& McEvoy, B. T. (2016). The literature review six steps to success (3rd ed.). California: SAGE Publications Ltd.

Mahlanze, H. T., \& Sibiya, M. N. (2017a). Perceptions of student nurses on the writing of reflective journals as a means for personal, professional and clinical learning development. Health SA Gesondheid, 22, 79-86. https://doi.org/10.1016/j.hsag.2016.05.005

Mahlanze, H. T., \& Sibiya, M. N. (2017b). Perceptions of student nurses on the writing of reflective journals as a means for personal, professional and clinical learning development. Health SA Gesondheid, 22, 79-86. https://doi.org/10.1016/j.hsag.2016.05.005 
Marsh, C. (2014). 'It's quite weird to write ... you feel like a nut job': The practical and emotional consequences of writing personal reflections for assessment in psychology. Reflective Practice, 15(2), 190-202. https:// doi.org/10.1080/14623943.2014.883310

Matousek, M. (2017). Writing to awaken: A journey of truth, transformation, and selfdiscovery. California: Reveal Press.

Michel, M., Kormos, J., Brunfaut, T., \& Ratajczak, M. (2019). The role of working memory in young second language learners' written performances. Journal of Second Language Writing, 45, 31-45. https:/ / doi.org/10.1016/j.jslw.2019.03.002

Moon, J. A. (2006). Learning journals: A handbook for reflective practice and professional development (2nd ed.). London: Routledge Taylor \& Francis Group.

Mujtaba, S. M., Parkash, R., \& Nawaz, M. W. (2020). Do indirect coded corrective feedback and teachers short affective comments improve the writing performance and learners uptake? Reading \& Writing Quarterly, 36(1), 34-47. https://doi.org/10.1080/10573569.2019.1616638

Murillo-Llorente, M. T., Navarro-Martínez, O., Valle, V. I., \& Pérez-Bermejo, M. (2021). Using the reflective journal to improve practical skills integrating affective and self-critical aspects in impoverished international environments: A pilot test. International Journal of Environmental Research and Public Health, 18(16), 8876. https://doi.org/10.3390/ijerph18168876

Nagao, A. (2018). A genre-based approach to writing instruction in EFL classroom contexts. English Language Teaching, 11(5), 130. https://doi.org/10.5539/elt.v11n5p130

Nagao, A. (2019). The SFL genre-based approach to writing in EFL contexts. Asian-Pacific Journal of Second and Foreign Language Education, 4(1), 6. https://doi.org/10.1186/s40862-019-0069-3

Or, P. (2018). Reflective journal writing of undergraduate students enrolled in sex education in Hong Kong. Reflective Practice, 19(5), 599-608. https:// doi.org/10.1080/14623943.2018.1538950

Park, J., Ayduk, Ö., \& Kross, E. (2016). Stepping back to move forward: Expressive writing promotes self-distancing. Emotion, 16(3), 349-364. https://doi.org/10.1037/emo0000121

Phillips, S. R., \& Archer-Lean, C. (2019). Decolonising the reading of Aboriginal and Torres Strait Islander writing: Reflection as transformative practice. Higher Education Research \& Development, 38(1), 24-37. https:// doi.org/10.1080/07294360.2018.1539956

Power, J. B. (2017). Not leaving the conversation behind: Approaching a decade of teaching reflective journal writing at a liberal arts college. Reflective Practice, 18(5), 713-724. https:// doi.org/10.1080/14623943.2017.1324417

Qin, L., \& Jun Zhang, L. (2019). English as a foreign language writers' metacognitive strategy knowledge of writing and their writing performance in multimedia environments. Journal of Writing Research, 11( 2), 393-413. https://doi.org/10.17239/jowr-2019.11.02.06

Ramadhanti, D., Ghazali, A. S., Hasanah, M., Harsiati, T., \& Yanda, D. P. (2020). The use of reflective journal as a tool for monitoring of metacognition growth in writing. International Journal of Emerging Technologies in Learning (IJET), 15(11), 162. https:// doi.org/10.3991/ijet.v15i11.11939

Reinertsen, A. B., \& Thomas, L. M. (2019). Stepping into the flow... lif/ve de-comforting academic writing: Smooth and striated spaces for being becoming performances. In L. Thomas \& A. Reinertsen (Eds.), Academic writing and identity constructions (pp. 1-11). Cham: Springer International Publishing. 
https://doi.org/10.1007/978-3-030-01674-6_1

Riley-Douchet, C., \& Wilson, S. (1997). A three-step method of self-reflection using reflective journal writing. Journal of Advanced Nursing, 25(5), 964-968. https:// doi.org/10.1046/j.1365-2648.1997.1997025964.x

Rushton, D., \& Duggan, C. (2013). Impact of culture on reflective writing in masters level students. Procedia - Social and Behavioral Sciences, 93, 956-963. https://doi.org/10.1016/j.sbspro.2013.09.310

Sangvanich, K., \& Chinokul, S. (2018). Reflective sketchbook journals for art education students in Thailand. International Journal of Education Through Art, 14(3), 319337. https://doi.org/10.1386/eta.14.3.319_1

Şentürk, B. (2021). Writing in the digital age. https://doi.org/10.4018/978-1-7998-65087.ch007

Shang, H.-F. (2019). Exploring online peer feedback and automated corrective feedback on EFL writing performance. Interactive Learning Environments, 1-13. https://doi.org/10.1080/10494820.2019.1629601

Shaw, P., \& Vassileva, I. (2009). Co-evolving academic rhetoric across culture; Britain, Bulgaria, Denmark, Germany in the 20th century. Journal of Pragmatics, 41(2), 290-305. https://doi.org/10.1016/j.pragma.2008.07.009

Snyder, H. (2019). Literature review as a research methodology: An overview and guidelines. Journal of Business Research, 104, 333-339. https://doi.org/10.1016/j.jbusres.2019.07.039

Stevens, D. D., Emil, S., \& Yamashita, M. (2010). Mentoring through reflective journal writing: A qualitative study by a mentor/professor and two international graduate students. Reflective Practice, 11(3), 347-367. https:// doi.org/10.1080/14623943.2010.490069

Suastra, I. M., \& Menggo, S. (2020). Empowering students' writing skill through performance assessment. International Journal of Language Education, 4(3). https://doi.org/10.26858/ijole.v4i3.15060

Sudirman, A., Gemilang, A. V., \& Kristanto, T. M. A. (2021). The power of reflective journal writing for university students from the EFL perspective. Studies in English Language and Education, 8(3), 1061-1079. https://doi.org/10.24815/siele.v8i3.19105

Szenes, E., \& Tilakaratna, N. (2021). Deconstructing critical reflection in social work and business: Negotiating emotions and opinions in reflective writing. Journal of $\begin{array}{llll}\text { English for Academic } & 100931 .\end{array}$ https:// doi.org/10.1016/j.jeap.2020.100931

Tai, J., Ajjawi, R., Bearman, M., \& Wiseman, P. (2020). Conceptualizations and measures of student engagement: A worked example of systematic review. In O. ZawackiRichter, M. Kerres, S. Bedenlier, M. Bond \& K. Buntins (Eds.), Systematic reviews in educational research methodology, perspectives and application (pp. 91-110). Wiesbaden: Springer Fachmedien Wiesbaden. https://doi.org/10.1007/978-3658-27602-7_6

Teng, M. F. (2020a). Tertiary-level students' English writing performance and metacognitive awareness: A group metacognitive support perspective. Scandinavian Journal of Educational Research, 64(4), 551-568. https:// doi.org/10.1080/00313831.2019.1595712

Teng, M. F. (2020b). The role of metacognitive knowledge and regulation in mediating university EFL learners' writing performance. Innovation in Language Learning and Teaching, 14(5), 436-450. https:// doi.org/10.1080/17501229.2019.1615493

Vassilaki, E. (2017). Reflective writing, reflecting on identities: The construction of writer identity in student teachers' reflections. Linguistics and Education, 42, 43-52. 
https://doi.org/10.1016/j.linged.2017.08.001

Williams, P. (2019). 'How to do things with words': Teaching creative writing as performance. New Writing, 1-13. https://doi.org/10.1080/14790726.2019.1629964

Woronchak, M., \& Comeau, G. (2016). The value of reflective journaling with advanced $\begin{array}{llll}\text { piano students. Reflective } & \text { 792-805. }\end{array}$ https://doi.org/10.1080/14623943.2016.1220937

Yang, P.-L. (2020). English journal writing on moodle for EFL college learners. In I. Management Association (Eds.), Language learning and literacy (pp. 191-210). IGI Global. https://doi.org/10.4018/978-1-5225-9618-9.ch010

Yoshihara, R., Kurata, A., \& Yamauchi, A. (2020). Reflective journals to explore struggles and difficulties of novice Japanese EFL university instructors. Reflective Practice, 21(1), 81-93. https://doi.org/10.1080/14623943.2019.1708714

Yu, W. M., \& Chiu, M. M. (2019). Influences on the reflection quality of journal writing: An exploratory study. Reflective Practice, 20(5), 584-603. https:// doi.org/10.1080/14623943.2019.1651712

Zabihi, R., Mehrani-Rad, M., \& Khodi, A. (2019). Assessment of authorial voice strength in L2 argumentative written task performances: Contributions of voice components to text quality. Journal of Writing Research, 11( 2), 331-355. https://doi.org/10.17239/jowr-2019.11.02.04

Zarrabi, F., \& Bozorgian, H. (2020). EFL students' cognitive performance during argumentative essay writing: A log-file data analysis. Computers and Composition, 55, 102546. https://doi.org/10.1016/j.compcom.2020.102546

Zou, D., \& Xie, H. (2019). Flipping an English writing class with technology-enhanced just-in-time teaching and peer instruction. Interactive Learning Environments, 27(8), 1127-1142. https://doi.org/10.1080/10494820.2018.1495654 